\title{
Analisis Hubungan antara Pengukuran Kinerja, Strategi dan Kinerja Perusahaan
}

Oleh:

\author{
Rudy J. Pusung
}

\begin{abstract}
ABSTRAK
Sebagai salah satu instrumen dalam menjalankan fungsi sistem pengendalian perusahaan, maka pemilihan dan penggunaan bentuk pengukuran kinerja yang sesuai dan selaras dengan kebutuhan perusahaan sangat diperlukan. Tujuan yang hendak dicapai dalam penelitian ini adalah untuk menganalisis penggunaan ukuran kinerja Nonfinansial mengindikasikan bahwa jenis ukuran kinerja tersebut apakah di pandang mampu untuk memberikan kontribusi yang cukup signifikan bagi peningkatan kinerja perusahaan.

Sampel yang digunakan dalam penelitian ini adalah perusahaan-perusahaan emiten yang terdaftar pada Bursa Efek Indonesia. Pengujian hipotesis dilakukan dengan menggunakan metode regresi linear berganda dengan metode Ordinary Least Square (OLS).

Hasil pengujian menunjukkan bahwa pilihan penggunaan ukuran kinerja mempengaruhi secara positif signifikan kinerja perusahaan. Selain itu juga, secara lebih spesifik hasil penelitian ini mampu menunjukkan bahwa kemampuan kombinasi ukuran kinerja finansial dan nonfinansial dalam meningkatkan kinerja perusahaan terbukti lebih tinggi dibandingkan dengan penggunaan ukuran kinerja finansial.
\end{abstract}

Kata Kunci: Pengukuran Kinerja, Strategi Perusahaan. Kinerja Perusahaan 


\section{PENDAHULUAN}

Pembahasan tentang pengukuran kinerja merupakan salah satu topik yang sangat menarik perhatian untuk didiskusikan. Pembahasan tidak hanya menarik perhatian kalangan praktisi yang menerapkannya, seperti para manajer perusahaan, akan tetapi juga menarik bagi kalangan akademisi dan para peneliti. Pentingnya peran pengukuran kinerja bagi perusahaan menjadi alasan utama perlunya topik ini terus dikembangkan. Hal ini karena pengukuran kinerja dapat diasumsikan sebagai sebuah cermin bagi perusahaan. Artinya bahwa pihak yang berkepentingan dapat menggunakan pengukuran kinerja sebagai salah instrumen untuk mengetahui kondisi perusahaan saat ini dan masa depan. Melalui pengukuran kinerja yang tepat dan akurat, maka perusahaan akan dapat memperoleh informasi yang tepat dan akurat pula tentang kondisi perusahaan saat ini berdasarkan pada usaha yang telah dilakukan sebelumnya, sekaligus kondisi masa depan perusahaan. Sehingga melalui informasi yang diperoleh tersebut, maka perusahaan dapat melakukan pengendalian dan perbaikan untuk memperoleh hasil yang optimal sesuai dengan tujuan yang telah ditetapkan.

Sebagai salah satu instrumen dalam menjalankan fungsi sistem pengendalian perusahaan, maka pemilihan dan penggunaan bentuk pengukuran kinerja yang sesuai dan selaras dengan kebutuhan perusahaan sangat diperlukan. Ittner dan Larcker (1998a) menyatakan bahwa pilihan untuk menggunakan ukuran kinerja adalah merupakan tantangan paling kritis dan menentukan yang dihadapi oleh perusahaan. Hal ini karena sistem pengukuran kinerja memainkan peranan penting dalam pengembangan beberapa unsur penting dalam perusahaan. Bentuk pengembangan tersebut meliputi pengembangan rencana strategis perusahaan, pengevaluasian pencapaian tujuan perusahaan, dan kompensasi manajer. Ketiga unsur tersebut dipandang merupakan unsur yang dapat menentukan pengembangan dan keberhasilan masa depan perusahaan. Dengan demikian, secara tidak langsung penggunaan sistem pengukuran kinerja yang sesuai dengan kebutuhan perusahaan akan memberikan kontribusi bagi pengembangan dan keberhasilan masa depan perusahaan.

\section{TINJAUAN PUSTAKA}

\subsection{PENELITIAN TERDAHULU}

Berkembangnya penggunaan ukuran kinerja non finansial mengindikasikan bahwa jenis ukuran kinerja tersebut dipandang mampu untuk memberikan kontribusi yang cukup signifikan bagi peningkatan kinerja perusahaan. Hal tersebut didukung oleh beberapa temuan penelitian. Pollanen dan Xi (2011) menemukan bahwa terdapat hubungan yang sangat kuat antara pengadopsian balanced scorecard, sebagai salah satu bentuk dari ukuran kinerja nonfinansial, dan kinerja perusahaan. Temuan tersebut sekaligus mendukung hasil penelitian yang juga telah dilakukan oleh Hoque dan James (2000) dan Davis dan Albright (2004). Penelitian-penelitian sebelumnya yang juga menguji hubungan antara penggunaan ukuran kinerja nonfinansial dan kinerja perusahaan, namun melalui penggunaan jenis ukuran kinerja nonfinansial yang berbeda dari penelitian Pollanen dan Xi (2011), dilakukan oleh Symon dan Jacobs (1995); Abernethy dan Lillis (1995); Chenhall (1997) dan Hirschey et al. (1998). Secara umum hasil dari penelitian-penelitian tersebut menunjukkan bahwa terdapat hubungan yang positif antara ukuran kinerja nonfinansial dan kinerja perusahaan. Symon dan Jacobs (1995) mengindikasikan bahwa penggunaan sistem ukuran kinerja nonfinansial yang berbasiskan TQM berhubungan dengan tingginya kinerja. Abernethy dan Lillis (1995) juga mengindikasikan bahwa semakin besar ketergantungan pada ukuran manufaktur nonfinansial memiliki pengaruh yang positif terhadap kinerja perusahaan. Chenhall (1997) menyimpulkan bahwa perusahaan yang menggunakan ukuran kinerja 
nonfinansial memperoleh kinerja yang lebih tinggi dalam bandingannya dengan perusahaan yang tidak menggunakan ukuran kinerja nonfinansial. Sedangkan, Hirschey et al. (1998) menyatakan bahwa dampak dari informasi ukuran kinerja nonfinansial memiliki pengaruh yang konsisten positif terhadap harga saham.

\subsection{LANDASAN TEORI}

\subsubsection{Pengukuran Kinerja Nonfinansial}

Meningkatnya bentuk persaingan usaha antar perusahaan secara tidak langsung telah membawa setiap perusahaan untuk saling berkompetisi dalam meningkatkan kinerja. Salah satu upaya secara internal yang dilakukan oleh perusahaan adalah dengan membenahi sistem pengendalian manajemen dengan meningkatkan kemampuan memperoleh informasi kondisi perusahaan melalui penambahan bentuk pengukuran kinerja yang lebih bersifat kontemporer. Kelemahan yang dimiliki pengukuran kinerja finansial yang bersifat tradisional telah memotivasi terjadinya inovasi variasi sistem pengukuran kinerja yang meliputi peningkatan terhadap kemampuan ukuran finansial seperti economic value sampai pada balance scorecard yang mengintegrasikan ukuran finansial dan nonfinansial.

Ittner \& Larcker (1998b) menyatakan bahwa berkembangnya sistem pengukuran kinerja yang berorientasi pada ukuran nonfinansial dilandasi oleh beberapa kelebihan yang dimiliki ukuran tersebut. Terdapat empat kelebihan yang dimiliki oleh ukuran nonfinansial jika dibandingkan dengan ukuran kinerja finansial yaitu: (1) ukuran nonfinansial berkaitan dengan strategi organisasi yang bersifat jangka panjang; (2) ukuran nonfinansial dapat membantu manajer untuk membuat keputusan yang lebih baik melalui indikator-indikator aset tak berwujud yang berkaitan dengan ukuran inovasi, kapabilitas manajemen, hubungan pekerja, nilai kualitas yang menjelaskan proporsi nilai perusahaan secara signifikan; (3) ukuran nonfinansial dapat menjadi indikator yang lebih baik untuk kinerja keuangan masa depan perusahaan, dan (4) ukuran nonfinansial tidak terlalu rentan terhadap noise eksternal dibandingkan dengan ukuran finansial, sehingga dapat meningkatkan kinerja manajer melalui pemberian evaluasi yang lebih tepat terkait tindakan yang telah dilakukan.

Beberapa keunggulan yang dimiliki oleh ukuran kinerja nonfinansial terhadap ukuran kinerja finansial tidak berarti bahwa ukuran tersebut tidak memiliki kelemahan. Sejumlah penelitian menunjukkan beberapa kelemahan yang secara umum melekat pada beberapa ukuran kinerja nonfinansial. Kelemahan-kelemahan tersebut diantaranya adalah terkait dengan banyaknya waktu dan kos yang dibutuhkan untuk menelusuri beberapa ukuran nonfinansial. Selain itu juga sulitnya menentukan denominator yang digunakan secara tetap untuk indikator ukuran menjadi salah satu kelemahan. Hal ini disebabkan karena data nonfinansial terkadang diukur dengan banyak cara. Sehingga terkadang dasar ukuran yang digunakan lebih banyak mengarah pada hal-hal yang bersifat kualitatif dan bukannya kuantitatif.

Pentingnya peran pengukuran kerja telah mendorong beberapa peneliti, khususnya para peneliti dalam bidang akuntansi manajemen, untuk mengembangkan penelitian yang mengarah pada topik-topik tentang pengembangan dan pengaplikasian jenis pengukuran kinerja. Salah satu topik yang banyak dibahas adalah pengembangan dan pengaplikasian jenis pengukuran yang bersifat prospektus bagi perusahaan, yaitu ukuran kinerja nonfinansial. Munculnya pandangan bahwa penggunaan ukuran kinerja tradisional berbasis finansial tidak lagi cukup handal untuk digunakan oleh perusahaan guna mengimbangi kebutuhan informasi yang bersifat jangka panjang, menjadi alasan utama yang memotivasi dikembangkannya ukuran kinerja berbasis nonfinansial (Ittner dan Larcker, 1998a). Fisher (1995) menyatakan bahwa terdapat tiga alasan prinsip 
mengapa perusahaan menggunakan ukuran kinerja nonfinansial, yaitu: (1) adanya keterbatasan dari ukuran kinerja finansial, (2) tekanan persaingan yang dihadapi perusahaan, dan (3) hasil pengembangan inisiatif dari perusahaan yang telah mengadopsi sistem produksi modern seperti total quality management (TQM).

Adanya pengembangan pengukuran kinerja berbasis informasi nonfinansial mendorong beberapa peneliti untuk melakukan pengujian terkait dengan penerapan dari pengukuran kinerja tersebut. Diantaranya adalah pengujian tingkat efektivitas dari penerapan pengukuran kinerja nonfinansial pada perusahaan (Amir \& Lev, 1996 dan Ittner \& Larcker, 1998b). Selain menguji efektivitas penerapan pengukuran kinerja nonfinansial, beberapa peneliti lain juga berupaya untuk menganalisa keterkaitan ukuran kinerja tersebut dengan beberapa unsur seperti: kinerja perusahaan meliputi kinerja masa kini dan masa depan, rencana strategi perusahaan, evaluasi tujuan, kompensasi manajer, eksternalitis dan penyusunan target (Said, HassabElnaby \& Wier, 2003; Widener, 2006; Hyvö nen, 2007 dan Hansen, 2010).

Terkait dengan pengujian efektivitas dari penerapan sistem pengukuran kinerja nonfinansial pada perusahaan, baik Amir \& Lev (1996) serta Ittner \& Larcker (1998b), berdasarkan pada hasil penelitian yang diperoleh, secara umum menyatakan bahwa penggunaan ukuran kinerja nonfinansial memberikan dampak yang positif bagi perusahaan. Salah satu dampak positif yang diberikan adalah terkait dengan adanya relevansi nilai dari pengunaan ukuran kinerja tersebut bagi investor. Implikasi dari adanya relevansi nilai tersebut memberikan kesempatan bagi investor untuk melakukan penilaian secara tepat tentang kondisi perusahaan, baik untuk kondisi saat kini, maupun untuk kondisi dimasa depan. Kemampuan investor untuk menilai kondisi perusahaan tersebut secara tidak langsung akan dapat memberikan kontribusi positif bagi perusahaan yang terrefleksikan melalui nilai perusahaan.

Sedangkan menyangkut penelitian tentang analisa keterkaitan antara ukuran kinerja nonfinansial dengan beberapa unsur yang disebutkan, masing-masing peneliti memberikan hasil penelitian yang cukup bervariasi. Dalam hubungannya dengan kinerja perusahaan, Said, Hassab Elnaby \& Wier (2003) menyatakan bahwa penggunaan ukuran nonfinansial yang melengkapi ukuran finansial dapat memberikan konsekuensi yang berbeda terhadap kinerja perusahaan, baik pada kinerja masa kini maupun pada masa depan. Hasil penelitian yang mereka lakukan secara umum mengindikasikan bahwa hubungan antara kombinasi penggunaan ukuran kinerja nonfinansial dan finansial dan kinerja perusahaan adalah bersifat kontinjen pada operasi perusahaan dan karakteristik persaingan yang dialami oleh perusahaan. Artinya bahwa ketepatan penggunaan ukuran kinerja yang dapat memberikan konsekuensi positif bagi kinerja perusahaan harus disesuaikan dengan karakteristik perusahaan. Widener (2006) dalam penelitiannya yang menguji hubungan antara perusahaan yang menekankan pada penggunaan human capital dan penggunan ukuran kinerja dalam pemberian kompensasi bonus menyatakan bahwa perusahaan yang menitikberatkan pada human capital dalam operasi perusahaan cenderung akan bergantung pada kombinasi penggunaan ukuran kinerja nonfinansial dan finansial dibandingkan dengan ukuran kinerja finansial semata-mata. Kondisi ini selanjutnya akan berimplikasi pada penentuan kontrak kompensasi bonus manajer puncak.

Beberapa hasil penelitian sebelumnya menunjukkan bahwa keberhasilan dalam penggunaan dan penerapan ukuran kinerja nonfinansial yang melengkapi ukuran finansial secara tepat akan dapat memberikan kontribusi positif bagi perusahaan. Bentuk kontribusi positif tersebut dapat terlihat pada adanya peningkatan kinerja perusahaan. Akan tetapi permasalahan utama yang seringkali muncul adalah terkait dengan kondisi kontijensi yang selalu melekat dalam hubungan antara keduanya. Salah 
satu faktor kontijensi yang ada adalah berkaitan dengan strategi yang digunakan oleh perusahaan. Berdasarkan pada kondisi tersebut, maka peneliti tertarik untuk melakukan pengujian pengaruh dari penggunaan kombinasi ukuran kinerja finansial dan nonfinansial terhadap kinerja perusahaan dengan mempertimbangkan faktor strategi perusahaan. Pertanyaan penelitian yang ingin dikemukakan yaitu: (1) apakah penggunaan kombinasi ukuran kinerja finansial dan nonfinansial dalam pengukuran kinerja akan lebih meningkatkan kinerja perusahaan dalam bandingannya dengan hanya menggunakan ukuran kinerja finansial? (2) apakah pengaruh dari faktor strategi perusahaan terhadap hubungan yang ada? Tujuan yang ingin dicapai adalah untuk memberikan bukti secara empiris dampak dari penggunaan kombinasian ukuran kinerja nonfinansial dan finansial terhadap kinerja perusahaan dengan mempertimbangkan faktor strategi tertentu yang digunakan perusahaan.

\subsection{HIPOTESIS}

\subsubsection{Kombinasi Pengukuran Kinerja dan Kinerja Perusahaan}

Meskipun penggunaan ukuran kinerja nonfinansial di sejumlah perusahaan sangat berkembang pesat, namun tidak berarti bahwa secara otomatis ukuran kinerja nonfinansial dapat menggantikan ukuran kinerja finansial. Hal ini karena meskipun memiliki sejumlah kekurangan, akan tetapi peran dari ukuran kinerja finansial akan tetap dibutuhkan perusahaan. Sejumlah literatur akuntansi secara luas mendiskusikan perlunya kombinansi antara penggunaan ukuran kinerja finansial dan nonfinansial. Ittner \& Larcker (1998a) menyatakan, dalam konteks analisa dengan mendasarkan pada teori-teori ekonomi, bahwa pilihan untuk menentukan ukuran kinerja yang akan digunakan sebaiknya berusaha untuk menggabungkan antara ukuran finansial dan nonfinansial yang dapat memberikan tambahan informasi yang lebih bermanfaat bagi usaha manajerial. Kekurangan yang dirasakan pada ukuran kinerja finansial tradisional tidak dengan otomatis mengarahkan perusahaan untuk menggunakan ukuran kinerja nonfinansial guna menggantikan ukuran kinerja finansial. Akan tetapi, sejumlah perusahaan berusaha untuk memperbaiki kelemahan yang ada sekaligus juga mengkombinasikannya dengan penggunan ukuran kinerja nonfinansial.

Kombinasi penggunaan ukuran kinerja finansial dan nonfinansial dipandang akan dapat memberikan kontribusi dalam bentuk tambahan informasi bagi manajemen melalui pemahaman dari dimensi yang berbeda terhadap tindakan manajerial yang telah dilakukan. Pernyataan tersebut didukung oleh literatur pengukuran kinerja yang berpendapat bahwa penggunaan kombinasi tersebut dapat membantu manajer untuk lebih memahami secara mendalam tentang hubungan diantara berbagai tujuan strategis, komunikasi hubungan antara tindakan pekerja dan sasaran, dan alokasi sumber daya dan penentuan skala prioritas berdasarkan pada tujuan perusahaan. Barua et al. (1995) menyatakan bahwa penggunaan kombinasi ukuran kinerja finansial dan nonfinansial akan memberikan umpan balik terkait aktivitas manajerial secara langsung dan tepat waktu kepada manajemen dibandingkan dengan hanya menggunakan ukuran kinerja finansial. Sehingga dengan demikian akan memberikan kesempatan bagi manajemen untuk dengan cepat dan tepat manajemen mengambil tindakan koreksi yang akan berdampak pada terjadinya peningkatan kinerja perusahaan.

Berdasarkan pada penjelasan yang telah diuraikan, maka peneliti menduga bahwa kontribusi dari ukuran kinerja finansial dalam memberikan informasi aktivitas manajerial bagi manajemen akan sangat membantu dalam upaya meningkatkan kinerja apabila dikombinasikan dengan ukuran kinerja nonfinansial. Hal ini karena kombinasi dari keduanya akan dapat mengatasi kelemahan yang ada dalam sistem pengukuran kinerja. Dengan demikian akan dapat memberikan informasi bagi manajemen secara 
lebih akurat, memadai dan komprehensif yang selanjutnya akan berdampak pada peningkatan kinerja perusahaan. Berdasarkan pada dugaan tersebut, maka penelitian ini menyatakan hipotesis:

H1: Perusahaan yang menggunakan kombinasi sistem ukuran kinerja finansial dan nonfinansial memiliki kinerja yang lebih tinggi dibandingkan dengan perusahaan yang hanya menggunakan sistem ukuran kinerja finansial.

\subsubsection{Pengukuran Kinerja, Strategi dan Kinerja Perusahaan}

Bentuk pemahaman terhadap hubungan antara sistem pengukuran kinerja dan kinerja perusahaan yang didasarkan pada latar belakang penentuan hipotesis sebelumnya, akan berbeda jika ditinjau dari sudut pandang teori kontijensi. Perbedaan tersebut terjadi karena berdasarkan pada teori kontijensi dinyatakan bahwa ketepatan pilihan atas teknik akuntansi manajerial dalam perusahaan akan sangat tergantung pada keadaan yang meliputi perusahaan tersebut (Otley, 1980). Artinya bahwa ketepatan dalam memilih jenis ukuran kinerja yang dapat memberikan kontribusi pada peningkatan kinerja tidak hanya berdasarkan pada kemampuan dari ukuran kinerja tersebut, akan tetapi juga dipengaruhi oleh faktor-faktor kontijensi yang terkait dengan karakteristik perusahaan. Sedangkan asumsi dasar yang melandasi latar belakang penentuan hipotesis sebelumnya adalah mengabaikan pengaruh dari karakteristik perusahaan ketika menguji konsekuensi kinerja yang disebabkan oleh ukuran kinerja yang digunakan.

Salah satu faktor kontijensi yang menjadi perhatian dalam penelitian ini adalah strategi bisnis perusahaan. Perhatian terhadap strategi bisnis perusahaan didasarkan pada pemikiran bahwa faktor ini sangat terkait dengan proses pemilihan ukuran kinerja perusahaan yang akan dipilih dalam upaya untuk meningkatkan kinerja perusahaan. Pada kondisi dimana tingkat persaingan antar perusahaan yang semakin kompetitif, maka kejelian dalam proses penentuan jenis ukuran kinerja yang akan digunakan sangat dibutuhkan. Kejelian tersebut berkaitan dengan kemampuan untuk memilih ukuran kinerja yang tepat, dengan mempertimbangkan faktor strategi bisnis yang dijalankan perusahaan, agar dapat memberikan kontribusi nyata untuk peningkatan kinerja perusahaan. Simon (1987) menyatakan bahwa organisasi yang mampu menyelaraskan dengan baik keterkaitan antara ukuran kinerja dan strategi akan mampu untuk memperoleh tingkat kinerja yang lebih tinggi. Kesesuaian antara ukuran kinerja dan strategi merupakan suatu kondisi harus diciptakan oleh perusahaan. Pernyataan yang dikemukakan tersebut secara implisit ingin menunjukkan bahwa tingkat efektivitas penggunaan ukuran kinerja untuk menunjang terjadinya peningkatan kinerja tidak dapat dilepaskan dari pengaruh strategi yang digunakan oleh perusahaan dalam mencapai tujuan. Ketidakmampuan jenis ukuran kinerja yang digunakan untuk memberikan kontribusi positif dalam upaya untuk peningkatan kinerja terkadang merupakan suatu permasalahan yang berawal dari ketidaksesuaian antara strategi dan ukuran kinerja yang dipilih.

Terkait dengan kondisi lingkungan persaingan yang kompetitif, Porter (1980) menyatakan bahwa terdapat dua jenis strategi bisnis perusahaan yang memiliki potensi untuk memberikan keuntungan bagi perusahaan, yaitu Product Differentiation Strategy dan Cost Leadership Strategy. Perusahaan yang menerapkan product differentiation strategy cenderung memfokuskan pada kepuasan konsumen yang membutuhkan tingkat kualitas produk yang tinggi, rancangan fitur khusus, penyerahan produk dengan cepat dan reliabel, dan dukungan purna jual yang efektif (Porter, 1985 dalam Jeremias \& Gani, 2005). Berdasarkan pada fokus tersebut, maka peningkatan kinerja akan diperoleh perusahaan jika menggunakan ukuran kinerja yang lebih mengarah pada jenis ukuran nonfinansial seperti diantaranya adalah ukuran kepuasan konsumen dan 
penyerahan produk yang tepat waktu dan reliabel (Jeremias \& Gani, 2005). Sedangkan, untuk perusahaan yang menerapkan cost leadership strategy cenderung akan berfokus pada kepastian proses produksi dengan tingkat efisiensi biaya yang tinggi. Sehingga kecenderungan penggunaan jenis ukuran kinerja finansial lebih tepat digunakan agar dapat memberikan kontribusi pada peningkatan kinerja perusahaan.

Berdasarkan pada uraian yang telah dinyatakan serta dihubungkan dengan dampak dari penggunaan kombinasi ukuran kinerja finansial dan nonfinansial terhadap kinerja perusahaan, maka penelitian ini menduga bahwa dampak dari penggunaan kombinasi ukuran kinerja finansial dan nonfinansial terhadap kinerja perusahaan yang diuraikan pada bagian sebelumnya akan berbeda ketika memperhatikan faktor strategi perusahaan. Artinya bahwa untuk perusahaan yang cenderung menerapkan strategi product differentiation, penggunaan kombinasi ukuran kinerja finansial dan nonfinansial akan berdampak pada terjadinya peningkatan kinerja. Sedangkan untuk perusahaan yang cenderung menerapkan strategi cost leadership, penggunaan kombinasi ukuran kinerja finansial dan nonfinansial tidak akan berdampak pada terjadinya peningkatan kinerja. Hal ini disebabkan penekanan dari strategi tersebut yang tidak membutuhkan informasi nonfinansial. Oleh karena itu hipotesis yang dinyatakan adalah sebagai berikut:

H2a: Perusahaan dengan kecenderungan strategi product differentiation dan menggunakan ukuran kinerja kombinasi finansial dan nonfinansial memiliki kinerja lebih tinggi dibandingkan dengan perusahaan yang hanya menggunakan sistem ukuran kinerja finansial

H2b: Perusahaan dengan kecenderungan strategi cost leadership dan menggunakan sistem ukuran kinerja finansial memiliki kinerja lebih tinggi dibandingkan dengan perusahaan yang menggunakan sistem ukuran kinerja kombinasi finansial dan nonfinansial.

\section{TUJUAN DAN MANFAAT PENELITIAN}

Sebagaimana uraian latar belakang masalah serta perumusannya, maka tujuan yang hendak dicapai dalam penelitian ini adalah :

1. Untuk menganalisis penggunaan ukuran kinerja Nonfinansial mengindikasikan bahwa jenis ukuran jinerja tersebut apakah di pandang mampu untuk memberikan kontribusi yang cukup signifikan bagi peningkatan kinerja perusahaan.

2. Menganalisis pula apakah pengaruh dari faktor strategi perusahaan terhadap hubungan yang ada?

Penelitian mengenai Analisis Hubungan Antara Pengukuran Kinerja, Strategi dan Kinerja Perusahaan sebagaimana disebutkan di atas diharapkan dapat member manfaat sebagaimana berikut :

1. Secara Teoritis Hasil Penelitian di harapkan dapat memberikan manfaat bagi perusahaan, terutama bagi perusahaan yang menggunakan ukuran kinerja kombinasi Finansial dan nonfinansial.

2. Tujuan yang ingin dicapai adalah untuk memberikan bukti secara empiris dampak dari penggunaan kombinasian ukuran kinerja nonfinansial dan finansial terhadap kinerja perusahaan dengan mempertimbangkan faktor strategi tertentu yang digunakan perusahaan. 


\section{METODA PENELITIAN}

\subsection{Sampel dan Data Penelitian}

Sampel yang digunakan dalam penelitian ini adalah perusahaan-perusahaan emiten yang terdaftar pada Bursa Efek Indonesia. Proses pemilihan sampel didasarkan pada beberapa kriteri, yaitu: (1) jenis perusahaan adalah perusahaan manufaktur, (2) menerbitkan laporan keuangan dalam peride tahun amatan yang dapat diakses, dan (3) menerbitkan laporan tahunan dalam peride tahun amatan yang dapat diakses. Data penelitian ini adalah terkait dengan data laporan keuangan tahunan dan laporan tahunan perusahaan publik manufaktur terdaftar di Bursa Efek Indonesia untuk periode pengamatan tahun 2008-2010. Data diperoleh dari Thomson Reuters Datastream, laporan keuangan tahunan dan laporan tahunan yang dipublikasikan oleh Bursa Efek Indonesia.

\subsection{Pengukuran Variabel Penelitian}

Variabel-variabel yang digunakan dalam penelitian ini, yang sesuai dengan hipotesis, adalah sebagai berikut.

(1) Kinerja Perusahaan.

Variabel kinerja perusahaan dalam penelitian ini dinyatakan dengan menggunakan proksi Return On Assets (ROA) sebagai indikator kinerja berbasis akuntansi. ROA diukur dengan laba sebelum pos luarbiasa dibagi dengan total aset.

(2) Ukuran Kinerja

Variabel ukuran kinerja dinyatakan dengan variabel Nonfinancial Measure (NFM). Variabel ini dinyatakan dalam bentuk dummy yang diberi skor 1 jika menggunakan ukuran non finansial yang melengkapi ukuran finansial, dan 0 jika hanya menggunakan ukuran finansial. Kriteria perusahaan menggunakan ukuran non finansial dan finansial melalui penggunaan balance scorecard di perusahaan yang diperoleh melalui penjelasan dalam laporan tahunan perusahaan.

(3) Strategi Cost Leadership

Variabel ini menunjukkan kecenderungan perusahaan untuk menggunakan strategi Cost Leadership. Variabel ini diukur dengan rasio penjualan terhadap total aset untuk mengetahui kecenderungannya. Ukuran ini digunakan dengan mengacu pada Gani dan Jermias (2006).

(4) Strategi Product Differentiation

Variabel ini menunjukkan kecenderungan perusahaan untuk menggunakan strategi Product Differentiation. Variabel ini diukur dengan rasio marjin kotor terhadap penjualan. Ukuran ini digunakan dengan mengacu pada Gani dan Jermias (2006).

(5) Interaksi ukuran kinerja dan Strategi Cost Leadership Variabel ini merupakan hasil dari interaksi antara NFM dan Cost Leadership. Ukuran variabel ini adalah berdasarkan pada hasil perkalian dari nilai variabel NFM dan nilai variabel Cost Leadership.

(6) Interaksi ukuran kinerja dan Strategi Product Differentiation

Variabel ini merupakan hasil dari interaksi antara NFM dan Product Differentiation. Ukuran variabel ini adalah berdasarkan pada hasil perkalian dari nilai variabel NFM dan nilai variabel Product Differentiation

(7) Leverage

Variabel ini merupakan variabel kontrol yang menyatakan tingkat perbandingan antara hutang dan ekuitas (debt to equity ratio). Variabel ini diukur dengan total kewajiban dibagi dengan dengan shareholder equity.

(8) Size

Variabel ini merupakan variabel kontrol yang menyatakan ukuran perusahaan. Variabel ini diukur dengan log total aset. 
(9) Growth

Variabel ini meruapakan variabel kontrol yang menyatakan tingkat pertumbuhan perusahaan. Variabel ini diukur dengan nilai pasar ekuitas ditambah nilai buku utang dibagi dengan nilai buku aset awal tahun.

\subsection{Model Penelitian}

Pengujian hipotesis dilakukan dengan menggunakan metode regresi linear berganda dengan metode Ordinary Least Square (OLS). Model penelitian yang digunakan adalah sebagai berikut.

ROA $=\alpha+\beta_{1}$ NFM $+\beta_{2}$ CL $+\beta_{3}$ Diff $+\beta_{4}$ NFM $^{*}$ CL $+\beta_{5}$ NFM $^{*}$ Diff $+\beta_{7}$ Lev $+\beta_{8}$ Size $+\beta_{9}$ Growth $+\varepsilon$

Dimana:

ROA adalah Return On Assets

NFM adalah Nonfinancial Measure

$C L$ adalah Cost Leadership

Diff adalah Product Differentiation

Lev adalah Leverage

\section{HASIL DAN PEMBAHASAN}

\subsection{Rincian Sampel dan Statistik Deskriptif}

Data yang digunakan adalah merupakan data perusahaan-perusahaan emiten yang terdaftar pada Bursa Efek Indonesia dengan periode amatan adalah tahun 20082010. Merujuk pada kriteria yang ada dalam penelitian ini, maka hanya perusahaan manufaktur yang dipilih menjadi sampel. Jumlah perusahaan manufaktur dalam periode amatan adalah sebanyak 142 perusahaan. Disebabkan oleh kelengkapan data, maka tidak semua perusahaan manufaktur yang diambil menjadi sampel akhir. Sampel akhir yang digunakan adalah berjumlah 79 perusahaan. Dengan demikian, jumlah data yang dianalisa adalah sebanyak 237. Rincian sampel penelitian disajikan pada Tabel 1.

\section{Tabel 1. Rincian Sampel Penelitian}

\begin{tabular}{|l|l|}
\hline Jumlah Sampel awal: & 142 perusahaan \\
\hline Laporan Keuangan tidak tersedia & $(14)$ \\
\hline Laporan Tahunan tidak tersedia & $(21)$ \\
\hline Data tidak lengkap & $(28)$ \\
\hline Sampel akhir: & 79 perusahaan \\
\hline
\end{tabular}

Hasil statisitik deskriptif variabel-variabel yang digunakan dalam penelitian ini disajikan pada Tabel 2. Hasil pada Tabel 2 menunjukkan bahwa variasi pada masingmasing variabel secara umum tidak terlalu menonjol. Khususnya pada variabel return on assets (ROA) yang merupakan proksi untuk kinerja dan menjadi variabel dependen. Tertunjukkan bahwa hampir sebagian besar data sampel tidak menunjukkan jumlah ROA yang terlalu tinggi. Hal tersebut dapat terlihat pada nilai mean yaitu sebesar 0,0814 dengan variansi sebesar 0,0140. Nilai ini mengindikasikan bahwa tingkat perbedaan kinerja antara masing-masing sampel perusahaan tidak terlalu besar. Indikasi yang sama juga ditunjukkan oleh variabel-variabel strategi, yaitu cost leader dan product differentiation. Sedangkan, untuk variabel-variabel kontrol, yaitu leverage, size dan growth, menunjukkan tingkat variasi yang cukup menonjol. Hal tersebut terlihat pada nilai variabel leverage yang memiliki varians cukup besar yaitu 23.472, dengan nilai mean 81,379 dan standar deviasi 153,29086. Hasil ini mengindikasikan bahwa 
terdapat jarak yang terlalu jauh untuk nilai leverage pada sampel perusahaan. Indikasi yang hampir sama juga ditunjukkan oleh variabel growth.

Tabel 2. Statistik Deskriptif Variabel

\begin{tabular}{cccccc}
\hline \hline Variabel & Mean & Std. Deviasi & Max & Min & Var. \\
\hline \hline ROA & 0,0814 & 0,1162 & 0,5680 & $-0,3940$ & 0,0140 \\
Cost Leader & 1,3476 & 0,6269 & 4,2600 & 0,3700 & 0,3930 \\
Prod Differ & 0,2096 & 0,1407 & 0,6428 & 0,0021 & 0,0200 \\
lev & 81,3791 & 153,2086 & 1282,2300 & 0,0010 & 23472,8770 \\
size & 12,2589 & 0,7444 & 14,3600 & 10,8900 & 0,5540 \\
growth & 1,7656 & 2,2131 & 16,8500 & 0,3000 & 4,8980 \\
& & & & & \\
$\mathrm{~N}=237$ & & & & & \\
\hline \hline
\end{tabular}

\subsection{Hasil Pengujian dan Pembahasan}

Hasil analisis dengan menggunakan regresi berganda berdasarkan model yang diajukan untuk menguji kedua hipotesis disajikan pada Tabel 3. Hasil yang dinyatakan pada Tabel 3 menunjukkan bahwa secara umum model yang digunakan dapat dinyatakan fit untuk mengukur pengaruh dari ukuran kinerja yang digunakan, strategi, dan interaksi antara ukuran kinerja dan strategi serta beberapa variabel kontrol yang digunakan (Leverage, Size dan Growth), terhadap kinerja perusahaan yang diproksikan dengan return on assets (ROA). Pernyataan ini dibuktikan pada nilai F-statistik yang diperoleh sangat signifikan dengan nilai sebesar 39,337 probabilitas 0,000 pada level signifikansi $1 \%(\mathrm{p}<0,01)$. Hal ini juga diperkuat dengan hasil $\mathrm{R}^{2}$ sebesar 0,58 yang berarti diatas $50 \%$ variasi perubahan ROA diterangkan oleh variabel-variabel independen yang ada dalam model.

Pada Tabel 3 juga tersajikan hasil pengujian untuk masing-masing variabel independen yang dipandang mempengaruhi kinerja perusahaan. Variabel NFM, yang dinyatakan dalam bentuk variabel dummy untuk kategori ukuran kinerja yang digunakan sampel perusahaan, menunjukkan hasil yang sesuai dengan prediksi. Nilai tstatistik sebesar 2,156 dengan probabilitas 0,032 menunjukkan bahwa koefisien untuk variabel ini signifikan secara statistik pada level signifikansi 5\% $(p<0,05)$. Hasil ini memperlihatkan bahwa variabel NFM berpengaruh secara signifikan terhadap kinerja perusahaan. Selain itu juga tanda nilai koefisien yang positif signifikan, seperti yang diharapkan, menunjukkan bahwa pengaruh penggunaan ukuran kinerja kombinasian secara signifikan mampu memberikan peningkatan kinerja yang lebih tinggi dalam bandingannya dengan penggunaan ukuran yang hanya berdasarkan pada ukuran finansial. Hasil analisa yang diperoleh tersebut mendukung hipotesis 1 yang diajukan dalam penelitian ini.

Hasil yang serupa dengan variabel NFM juga diperoleh variabel strategi yang dalam penelitian ini dijabarkan dalam dua bentuk, yaitu: cost leadership dan product differentiation.Kedua variabel tersebut, cost leadership dan product differentiation, memperoleh nilai t-statistik, masing-masing sebesar 3,522 dan 2,685 dengan probabilitas 0,001 dan 0,008 . Nilai-nilai yang diperoleh tersebut menunjukkan bahwa koefisien pada kedua variabel tersebut signifikan secara statistik pada level signifikansi $5 \%(p<0,05)$. Hasil ini menunjukkan bahwa penggunaan kedua strategi tersebut secara signifikan berpengaruh terhadap kinerja perusahaan. Tanda pada nilai koefisien yang positif, seperti yang diprediksi, mengandung arti bahwa kedua pengaruh dari kedua strategi tersebut terhada kinerja perusahaan adalah positif secara statistik, sehingga 
dapat diasumsikan bahwa penggunaan kedua strategi tersebut akan dapat meningkatkan kinerja perusahaan.

Hasil pengujian selanjutnya yang dinyatakan dalam Tabel 3 adalah terkait dengan pengujian pengaruh dari interaksi antara penggunaan ukuran kinerja dan strategi perusahaan terhadap kinerja perusahaan. Hasil pengujian menunjukkan bahwa nilai tstatistik untuk interaksi NFM dengan strategi cost leadership adalah sebesar -1,633 dengan probabilitas 0,104. Hasil ini menunjukkan bahwa koefisien interkasi kedua variabel (NFM*Cost Leadership) tersebut tidak signifikan secara statistik. Hasil yang sama juga diperoleh untuk pengujian pengaruh interaksi NFM dengan strategi product differentiation terhadap ROA. Nilai t-statistik yang diperoleh adalah 0,596 dengan probabilitas 0,552, yang berarti bahwa pengaruh interaksi NFM dengan strategi product differentiation terhadap kinerja tidak signifikan secara statistik. Hasil dari pengujian pengaruh kedua interaksi terhadap kinerja yang tidak signifikan memperlihatkan bahwa hipotesis 2 ( 2 a dan $2 b$ ) tidak terdukung.

Hasil pengujian lainnya yang ditunjukkan pada Tabel 3 adalah pengujian variabel-variabel kontrol, yaitu leverage, Size, dan Growth, terhadap ROA. Hasil pengujian yang diperoleh untuk variabel leverage yaitu nilai t-statistik adalah sebesar 2,313 dengan probabilitas 0,022. Artinya bahwa leverage berpengaruh negatif signifikan secara statistik terhadap kinerja perusahaan pada level signifikansi 5\% $(p<0,05)$. Selanjutnya, variabel size memperoleh t-statistik adalah sebesar 4,062 dengan probabilitas 0,000 . Ini menunjukkan bahwa size berpengaruh positif signifikan secara statistik terhadap kinerja perusahaan pada level signifikansi $1 \%(p<0,01)$. Sedangkan yang terakhir, yaitu variabel growth. Variabel growth memperoleh t-statistik sebesar 9,761 dengan probabilitas 0,000. Sama seperti variabel size, variabel growth juga berpengaruh positif signifikan secara statistik terhadap kinerja perusahaan pada level signifikansi $1 \%(p<0,01)$. Secara keseluruhan tanda koefisien dari ketiga variabel kontrol tersebut sesuai dengan yang diprediksi.

Tabel 3. Hasil Regresi dari Return On Assets, Kombinasi Ukuran Kinerja, dan Strategi Perusahaan

\begin{tabular}{lcccc}
\hline \multicolumn{1}{c}{ Variabel } & $\begin{array}{c}\text { Tanda } \\
\text { Prediksi }\end{array}$ & $\begin{array}{c}\text { Nilai Koefisien } \\
\text { Regresi }\end{array}$ & $\begin{array}{c}\text { Nilai } \\
\text { t-Test }\end{array}$ & $\begin{array}{c}\text { Tingkat } \\
\text { Signifikansi }\end{array}$ \\
\hline Konstanta & $?$ &,- 411 & $-4,193$ & 0,000 \\
NFM & + &, 166 & 2,156 & $0,032^{* * *}$ \\
Cost Leader & + &, 031 & 3,522 & $0,001^{* *}$ \\
Prod Differ & + &, 115 & 2,685 & $0,008^{* *}$ \\
NFM * Cost Leader & - &,- 130 & $-1,633$ & 0,104 \\
NFM * Prod Differ & + &, 143 & 0,596 & 0,552 \\
Lev & - & -005 & $-2,313$ & $0,022^{* *}$ \\
Size & + &, 031 & 4,062 & $0,000^{* * *}$ \\
Growth & + &, 032 & 9,761 & $0,000^{* * *}$
\end{tabular}

Nilai F-test $\quad 39,337$

Probabilitas $0.000^{* * * *}$

$\mathrm{R}^{2} \quad, 580$

Adjusted $\mathrm{R}^{2} \quad, 565$

*** Signifikan pada 1\% ; ** Signifikan pada 5\% ; $*$ Signifikan pada $10 \%$

NFM (Nonfinancial Measure) diukur dengan menggunakan variabel dummy, yaitu: 1= kombinasi ukuran finansial dan nonfinansial ; $0=$ penggunaan ukuran finansial. 


\subsection{Pembahasan}

Hasil Pengujian dan analisis yang dilakukan memperlihatkan sejumlah temuan empiris. Temuan empiris tersebut terkait dengan dampak dari penggunaan ukuran kinerja terhadap kinerja perusahaan serta pengaruh dari karakteristik perusahaan terhadap hubungan antara ukuran kinerja dan kinerja. Secara umum, temuan penelitian ini yang menunjukkan bahwa penggunaan ukuran kinerja dapat mempengaruhi kinerja. Temuan ini konsisten dengan temuan dari beberapa penelitian sebelumnya seperti: Pollanen dan Xi (2011), Symon dan Jacobs (1995); Abernethy dan Lillis (1995); Chenhall (1997) dan Hirschey et al. (1998). Akan tetapi, berbeda dengan penelitianpenelitian sebelumnya, penelitian ini mencoba untuk memberikan bukti empiris bahwa penggunaan ukuran kinerja yang dapat meningkatkan kinerja haruslah didasari pada pemilihan ukuran kinerja yang tepat. Ketepatan dalam pemilihan kinerja yang dimaksudkan dalam penelitian ini adalah bagaimana manajemen mampu untuk melihat kemungkinan lain dalam penggunaan ukuran kinerja dengan tidak hanya terpaku pada menggunakan salah satu ukuran kinerja tertentu. Kemampuan manajemen dalam memilih kombinasi ukuran kinerja yang akan diterapkan mengindikasikan bahwa adanya upaya dari manajemen untuk meningkatkan kinerja. Penggunaan ukuran kinerja yang berbasis finansial secara tunggal dalam perusahaan yang selama ini telah digunakan tidak berarti bahwa ukuran kinerja tersebut tidak dapat dikombinasikan. Pandangan untuk mendikotomikan antara ukuran kinerja finansial dan nonfinansial sudah selayaknya dihentikan demi upaya untuk meningkatkan kemajuan perusahaan. Hasil penelitian ini membuktikan bahwa penggunaan ukuran kinerja yang dikombinasikan mampu untuk meningkatkan kinerja.

Terkait dengan mempertimbangkan faktor kontijensi pada hubungan antara penggunaan ukuran kinerja dan kinerja perusahaan, hasil dari penelitian ini belum dapat memberikan bukti yang memadai. Hal ini dapat dilihat pada tidak terdukungnya hipotesis 2. Akan tetapi, jika dilihat arah terhadap hasil yang diharapkan dari pengujian yang dilakukan sudah menunjukkan sesuai dengan harapan. Hal ini dapat dilihat pada tanda koefisien pada masing-masing variabel. Tanda tersebut secara tidak langsung berusaha untuk menunjukkan bahwa sebenarnya faktor strategi memiliki pengaruh dalam kaitan antara penggunaan ukuran kinerja dan kinerja perusahaan. Arah negatif pada interaksi dari NFM dan strategi cost leadership, secara tidak langsung menunjukkan bahwa penggunaan kombinasi ukuran kinerja finansial dan nonfinansial tidak efektif digunakan pada perusahaan yang memiliki kecenderungan menggunakan strategi strategi cost leadership. Demikan pula sebaliknya dengan tanda yang ditunjukkan pada interaksi dengan strategi product differentiation.

\section{KESIMPULAN DAN SARAN}

6.1 Kesimpulan

Penelitian ini, secara umum, bertujuan untuk menguji pengaruh dari penggunaan ukuran kinerja terhadap peningkatan kinerja perusahaan. Secara spesifik menguji dampak dari penggunaan kombinasi ukuran kinerja finansial dan nonfinansial terhadap kinerja dalam bandingannya dengan hanya menggunakan ukuran kinerja finansial. Selain itu juga, dalam konteks teori kontijensi, penelitian ini menguji pengaruh dari strategi perusahaan dalam memahami hubungan antara penggunaan ukuran kinerja dan kinerja perusahaan.

Hasil pengujian menunjukkan bahwa pilihan penggunaan ukuran kinerja mempengaruhi secara positif signifikan kinerja perusahaan. Hasil ini mendukung temuan penelitian sebelumnya yang menyatakan bahwa terdapat hubungan yang positif antara penggunaan ukuran kinerja dan peningkatan kinerja perusahaan. Selain itu juga, 
secara lebih spesifik hasil penelitian ini mampu menunjukkan bahwa kemampuan kombinasi ukuran kinerja finansial dan nonfinansial dalam meningkatkan kinerja perusahaan terbukti lebih tinggi dibandingkan dengan penggunaan ukuran kinerja finansial. Temuan ini secara tidak langsung telah menunjukkan bahwa penggunaan ukuran kinerja nonfinansial yang selama ini dipandang tidak dapat memberikan kontribusi positif bagi perusahaan dengan berbagai kelemahan yang ada, tidaklah tepat. Akan tetapi penelitian ini belum dapat membuktikan pengaruh dari faktor strategi perusahaan terhadap hubungan antara penggunaan ukuran kinerja dan peningkatan kinerja perusahaan.

\subsection{Saran}

Mengacu pada hasil temuan dalam penelitian ini. Maka hal - hal penting yang perlu disarankan untuk ditindak lanjuti oleh pihak - pihak terkait adalah sebagai berikut

1. Ketidak mampuan ukuran yang digunakan dalam penelitian ini untuk mengetahui kecenderungan penggunaan strategi yang digunakan perusahaan menjadi kendala dalam membuktikan pengaruh dari faktor strategi terhadap hubungan dari penggunaan ukuran kinerja dan kinerja perusahaan.

2. kelemahan lain yang dirasakan oleh peneliti adalah terkait dengan hanya menggunakan salah satu faktor kontijensi dalam menjelaskan pengaruh dari faktor kontijensi terhadap hubungan ukuran kinerja dan kinerja perusahaan. Peneliti berharap hal ini dapat menjadi terobosan bagi pengembangan penelitian ke depan. Sehingga dimasa depan pengembangan pemahaman tentang penggunaan ukuran kinerja dan pengaruhnya terhadap peningkatan kinerja semakin banyak diperoleh.

\section{DAFTAR PUSTAKA}

Abernethy, M.A., Lillis, A.M., 1995. The impact of manufacturing flexibility on management control system design. Accounting, Organizations and Society 20, 241-1241.

Amir, E., Lev, B., 1996. Value-relevance of nonfinancial information: The wireless communications industry. Journal of Accounting and Economics 22 (1-3), 3-30

Barua, A., Kriebel, C. and Mukhopadhyay, T. 1995. Information Technologies and Business Value: An Analytic and Empirical Investigation. Information Systems Research, 6(1), 3-23

Chenhall, R.H., 1997. Reliance on manufacturing performance measures, total quality management and organizational performance. Management Accounting Research 8 (2), 187-206.

Fisher. 1995. Use of nonfinancial performance measures. In Readings in Management Accounting, edited by S.M. Young, 329-335. Englewood Cliffs, NJ: Prentice Hall.

Gani, L. \& Jeremias, J. 2006. Investigating The Effect of Board Independence on Performance Across Different Strategies.The International Journal of Accounting.

Govindarajan, V., and A. K. Gupta. 1985. Linking control systems to business unit strategy: Impact on performance. Accounting, Organizations and Society 10: 5166.

Hirschey, M., V. Richardson, and S. Scholz. 1998. Value relevance of nonfinancial information: The case of patent data. Working paper, University of Kansas.

Hyvö nen, J., 2007. Strategy, Performance Measurement Techniques and Information Technology of The Firm and Their Link to Organizational Performance. Journal of Management Accounting Research (18): 343-366 
Ittner, C.D., Larcker, D.F., 1998b. Are nonfinancial measures leading indicators of financial performance? An analysis of customer satisfaction. Journal of Accounting Research 36: 1-35.

Ittner, C.D., Larcker, D.F., 1998a. Innovations in performance measurement: Trends and research implications.Journal of Management Accounting Research (10): 205-238.

Jeremias, J. \& Gani, L. 2005. Ownership Structure, Contingent-Fit, and Business-Unit Performance: A Research Model and Empirical Evidence. The International Journal of Accounting.

Pollanen, R, M., \& Xi, Kenneth, K. 2011. The Use of Balance Scorecard Measure in Executive Incentive and Firm Performance. American Accounting Association Mid-Atlantic Meeting.

Porter, M.E., 1985. Competitive advantage. Free Press, New York.

Porter, M.E., 1980. Competitive strategy. Free Press, New York.

Said, A.A., HassabElnaby, H.R., Wier, B., 2003. An empirical investigation of the performance consequences of nonfinancial measures. Journal of Management Accounting Research 15, 193-223

Simons, R., 1987. Accounting control systems and business strategy: an empirical analysis. Accounting, Organizations and Society 12 (4), 357-374.

Simons, R., 1987. Accounting control systems and business strategy: an empirical analysis. Accounting, Organizations and Society 12 (4), 357-374.

Widener, S,K. 2006. Human Capital, Pay Structure, and Use of Performance Measure In Bonus Compensation. Journal of Management Accounting Research (17): 198221. 